PUSTABIBLIA: Journal of Library and Information Science

ISSN 2549-3493 (Print); ISSN 2549-3868 (Online)

DOI: http://dx.doi.org/10.18326/pustabiblia.v4i1.129-146

SK Dirjen Risbang-Kemristekdikti No 23/E/KPT/2019 (Peringkat 4 SINTA)

\title{
Evaluasi Koleksi Perpustakaan Berdasarkan Pandangan Edward G. Evans dan Elizabeth Futas
}

\author{
Siti Munisah \\ Mahasiswi pascasarjana IPI UIN Sunan Kalijaga Yogyakarta \\ Email: sitimunisah622@gmail.com
}

\begin{abstract}
Evaluation of the collection as part of the activity of collection development the library has a significant influence for the existence of the collection in the library. Course evaluation activities collection it is the idea or the important thing towards the improvement of the collection, to be able to better understand, observe, correct and weighing the collection for the improvement and advancement of the library collection. Technically written by Evans and Futas, both of which have standards and processes as well as methods in the evaluation of such a collection, which can be used as reference material or input for the evaluation activities of the collection. The formulation of the problem in this thesis is to understand how to view or how to describe the evaluation of the collection of the views of evans and futas with a more concise and clear. The method used in this paper is a literature study with a description of the analysis of the writings of Edvans and Futas directly with the reinforced by the writing of other works. The results of this paper is to describe the theory of the evaluation of the collection according to the authors of Evans and Futas on the procedures and methods of evaluation of library collections, the summary is clearly based on the writings of both the authors who the author is. The conclusion of the second author (Evans and Futas), which are from both the evaluation of the collection the library has the means and methods are almost the same in doing so, the need and importance of evaluation of the collection is a means of planning against the collection in a library.
\end{abstract}




\begin{abstract}
Abstrak
Tujuan dari penulisan ini yaitu untuk dapat memahami bagaimana kegiatan evaluasi pada koleksi di perpustakaan menurut teori dari Evans dan Futas, dimana tulisan keduanya telah banyak menginsfirasi dan menjadi rujukan bagi dunia perpustakaan. Evaluasi koleksi sebagai bagian dari aktivitas pengembangan koleksi perpustakaan memiliki pengaruh yang cukup signifikan bagi keberadaan koleksi di perpustakaan. Tentunya kegiatan evaluasi koleksi itu merupakan ide atau hal penting terhadap perbaikan koleksi, untuk dapat lebih memahami, mengamati, mengoreksi dan menimbang koleksi bagi perbaikan dan kemajuan koleksi perpustakaan. Secara tekhnis yang dituliskan oleh Evans dan Futas, yang keduanya memiliki standar dan proses serta metode dalam evaluasi terhadap koleksi tersebut, yang dapat dijadikan bahan rujukan atau masukan bagi kegiatan evaluasi koleksi. Adapun rumusan permasalah dalam penulisan ini yaitu memahami bagaiman pandangan atau cara mendeskripsikan evaluasi koleksi dari pandangan evans dan futas tersebut dengan lebih singkat dan jelas. Metode yang digunakan dalam penulisan ini adalah study pustaka dengan deskripsi analisis dari tulisan Edvans dan Futas secara langsung dengan diperkuat oleh tulisan karya lain. Hasil dari penulisan ini adalah mendeskripsikan teori dari evaluasi koleksi menurut penulis Evans dan Futas tentang tata cara dan metode evalusi koleksi perpustakaan, ringkasan secara jelas yang berdasarkan atas tulisan dari kedua penulis yang penulis tersebut. Kesimpulan dari kedua penulis (Evans dan Futas) tersebut yaitu dari keduanya evaluasi koleksi perpustakaan memiliki cara dan metode yang hampir sama dalam melakukannya, kebutuhan dan pentingnya evaluasi koleksi merupakan sarana perencanaan terhadap koleksi dalam sebuah perpustakaan.
\end{abstract}

Kata Kunci: Evaluasi Koleksi, Pengembangan koleksi, Evaluasi, Pengarang.

\title{
Pendahuluan
}

Pengertian buku secara luas yaitu mencakup semua tulisan dan gambar yang ditulis dan dilukiskan atas segala macam lembaran papirus, lontar, perkamen, dan kertas dengan segala bentuknya yang berupa: gulungan, yang dilubangi dan diikat dengan atau dijilid muka belakangnya dengan kulit, kain, karton, dan kayu (Ensiklopedi Indonesia, 1980). Atau dalam pengertian lain buku juga diartikan sebagai "informasi tercetak diatas kertas yang dijilid menjadi satu kesatuan." Dengan batasan buku dalam publikasinya tercetak, 
bukan berkala, yang sedikitnya sebanyak 49 halaman yang dapat dijadikan salah satu sumber dalam proses belajar dan membelajarkan. Buku secara asal muasal terdiri dari beberapa kata: dalam bahasa Yunani adalah biblia, bahasa Jerman Biblioteek, bahasa Prancis Bibliotheque, dalam bahasa Spanyol/ Portugis Bibliotheca. Catatan sejarah menuliskan diperkirakan buku pertama kali lahir pada tahun 2400 sebelum masehi, di Mesir dalam bentuk papirus yaitu sejenis kertas yang terbuat dari bahan-bahan rumput yang berasal dari sekitar sungai nil, yang dengan caranya papirus tersebut dihaluskan yang kemudian berfungsi untuk alat tulis, dimana papirus tersebut saat itu menjadi buku tidak dalam bentuk seperti sekarang ini tetapi berbentuk gulungan. Dalam tulisan lain mencatat sejarah buku dari beberapa negara seperti kamboja dan cina, dalam sejarah kamboja buku ada dalam sejarah Buddha dan dalam bentuk daun, sedangakan dalam sejarah cina menuliskan para cendekiawan menuliskan ilmu-ilmunya diatas lidi yang diikat menjadi satu (Wiji Suwarno, 2011).

Pada perkembangan selanjutnya keberadaan buku mengalami perkembangan sesuai dengan masanya, saat ini produksi buku pun telah mengalami perkembngan yang luar biasa. Semakin banyak penulis dari berbagai disiplin ilmu yang semakin berkembang dan diproduksi dengan lebih apik dan lebih modern, dalam dunia perpustakaan kumpulan dari membludaknya buku-buku tersebut disebut koleksi. Koleksi perpustakaan kaitannya dengan fungsi perpustakaan sebagai tempat menyimpan kahzanah budaya dan ilmu pengetahuan, informasi, perpustakaan memiliki peran dalam meningkatkan apresiasi budaya dari masyarakat sekitar melalui penyediaan bahan bacaan atau koleksi buku-buku, diamana penyediaan bahan bacaan ini dapat menghibur sekaligus memberikan nilai bagi pendidikan, seni, pengetahuan, dan lainnya (Syihabuddin Qalyubi, 2017)

Memahami pembinaan koleksi perpustakaan dapat dinilai dari isi perpustakaan harus mencerminkan dan sesuai dengan kemajuan-kemajuan manusia disegala bidang, oleh karenanya secara kontinyu bahan-bahan baru harus ditambahakan. Perpustakaan yang koleksi informasi jarang atau tidak pernah ditambah atau diperbaharui dengan koleksi terbitan 
baru, tentu saja akan ketinggalan zaman, dan para pemakai lambat laun akan berkurang (Noerhayati S. 1998), Yang diamksud dengan koleksi perpustakaan yang sesuai dengan zaman/masa kini yaitu bahan koleksi yang tidak hanya dalam bentuk tercetak akan tetapi termasuk juga semua media yang memuat nilai pengetahuan dan informasi yang dikoleksi perpustakaan sesuai dengan tugas pokok dan fungsinya, media yang merupakan materi informasi terekam tersebut seperti film, CD/DVD, CD-ROM, dan jenis media lain yang dapat diakses media terpasang (online). Pada dasarnya koleksi perpustakaan merupakan kumpulan bahan yang tersedia diperpustakaan yang merupakan kesatuan unit informasi yang berbentuk tercetak dan terekam yang dikumpulakan, diolah, dan disimpan untuk disajikan kepada pemustaka sebagai masayarakat pengguna (Hartono, 2016). Diambil dari Yueh-Min Huang and Ying-Hong Pu (2015) dari artikelnya tentunya dalam perkembangan koleksi selanjutnya seperti yang telah dikemukakan, bahwa kegiatan pengembangan merupakan sarana atau model untuk menggunakan kualitas informasi, kualitas sistem, kualitas layanan, kegiatan untuk menggunakan/penggunaan, kepuasan pengguna dan keuntungan secara keseluruhan untuk mengevaluasi keberhasilan suatu koleksi/sistem. Dengan kata lain evaluasi koleksi merupkan sarana dalam mengembangkan koleksi dan memeliharanya serta bagaimana evaluasi itu dilaksanakan. Merupakan salah satu kriteria dalam penilaian layanan perpustakaan yang baik dan berhasil adalah dinilai dari kualitas koleksinya. Maka dengan demikian, kriteria evaluasi koleksi yang ditetapkan harus berkaitan erat dengan maksud dan tujuan tersebut (Syukrinur, 2017). Pada artikel ini penulis akan membahas secara singkat dan jelas mengenai evaluasi koleksi perpustakaan menurut Evans G. Edward dan Elizabeth Futas, yang merupakan bagian dari pengembangan koleksi perpustakaan. Menurut Evans pandangan tentang evaluasi perpustakaan merupakan telah ada sejak 1990an dan merupakan kegiatan untuk menilai, hasil dan akuntabilitas dari kegiatan perpustakaan terhadap koleksinya. Sedangkan menurut pendapat futes yaitu sebuah proses menilai kekuatan dan kelemahan koleksi perpustakaan untuk mendapatkan koleksi yang lebih baik dan lebih berguna bagi pemustaka. 


\section{Pembahasan}

\section{Kebijakan Pengembangan Koleksi Perpustakaan}

Kebijakan berasal dari kata dasar bijak yang berarti selalu menggunakan akal budi, kebijakan adalah selalu berdasarkan ilmu yang memberi arah (sense of direction). Kebijakan pengembangan koleksi selalu berkaitan dengan perkembangan teknologi informasi dan komunikasi. Lambat laun, koleksi perpustakaan sudah dapat disajikan dalam bentuk digital/e-book. Perpustakaan seharusnya sudah harus mengadopsi terhadap perkembangan teknologi informasi agar setiap kebijakan dapat direalisasikan dengan pemahaman yang memadai tidak hanya sebatas koleksi monograf/buku, akan tetapi juga koleksi perpustakaan dalam bentuk non buku seperti: bahan garafis, CD/VCD, bahan kartografis, koleksi artefak dan koleksi dalam bentuk digital seperti e-journal dan e-book (Hartono, 2015).

Pengembangan koleksi menurut M. Solihin (2003) tidak hanya mencakup kegiatan pengadaan bahan pustaka, tetapi juga menyangkut masalah perumusan kebijakan dalam memilih dan menentukan bahan pustaka mana yang akan diadakan serta meode-metode apa yang akan diterapkan. Kebijakan pengembangan koleksi merupakan alat perencanaan atau sarana untuk mengkomunikasikan tujuan dan kebijakan pengembangan koleksi. Fungsi kebijakan pengembangan koleksi sebagai sarana perencanaan, pendanaan, pemilihan, dan pengadaan koleksi, Maka berfungsi sebagai pedoman, sarana kominukasi, dan perencanaan sebagai berikut :

1. Menjelaskan cakupan koleksi dan perencanaannnya

2. Memberikan deskripsi yang sistematis dan strategis bagi perpustakaan

3. Sebagai pedoman

4. Sebagai standar atau tolak ukur untuk sarana pengembangan koleksi

5. Sumber informasi dan panduan staff baru dalam posisi pengembangan koleksi

6. Memperlancar koordinasi antar staff bagian pengembangan koleksi

7. Memperlancarkerjasama antar perpustakaan dalam bidang pengembangan koleksi 
8. Membantu menjaga kntinuitas dan transisi dalam kinerja pustakawan

9. Membantu menghadapi pengaduan

10. Mengurangi pengaruh selector tertentu dan bias atau selera pribadi

\section{Pertanggungjawaban alokasi anggaran}

12. Menjadi sarana komunikasi

Kegiatan evaluasi sendiri adalah melengkapi siklus pengembangan koleksi dan membawa sesuatu kembali dalam kegiatan penilaian kebutuhan (evans, 2005). Ada banyak kriteria untuk menentukan nilai suatu buku atau dari seluruh koleksi :

1. Jenis bahan dan nilai mereka dalam kaitannya dengan materi lainnya yang bukan di perpustakaan yang dapat dinilai sehari-hari oleh pustakawan, kegiatan ini dapat dinilai oleh pustakwan terhadap permintaan atau minat terhadap koleksi.

2. Kriteria untuk menetapkan nilai untuk koleksi perpustakaan untuk masyarakat yang dilayani. Hal ini berkaitan dengan hubungan antara kebutuhan amsayarakat dan koleks perpustakaan disisi lain dan hubungan anatara koleksi perpustakaan dengan kebutuhan pengguna tertentu di sisi lainya.

3. Penilaian dari pengetahuan untuk tujuann koleksi memenuhi kebutuhan komunitas pengguna.

Sedangkan menurut Futas, yaitu bahwa kegiatan tersebut menekankan pada seleksi dan pemilihan dalam pengembangan koleksi, yang berupa maintenance dan pengelolaan koleksi yang ada.

\section{Rumusan kebijakan pengembangan koleksi}

Koleksi perpustakaan menurut Sulistyo Basuki (2010) terbagi dalam/ mencakup koleksi-koleksi sebagai berikut, yaitu :

1. Karya cetak atau karya grafis, yang meliputi buku, majalah, surat kabar, disertasi, dan laporan.

2. Karya non cetak yaitu, seperti karya rekam. Yang terdiri dari : piringan hitam, rekaman audio, kaset, dan video. 
3. Bentuk mikro : microfilm, mikrofis, microopaque.

4. Karya berbentuk elektronik seperti: disket, pita magnetic, kelongsong elektronik (cartridge)

5. Materi yang di asosiasikan dengan mebutuhkan perangkat computer.

6. E-book

Rumusan dalam kebijakan pengembangan koleksi sendiri tercatat dan dimulai dengan penjelasan dari visi dan misi perpustakaan dan sarana yang ingin dicapai, deskripsi singkat masyarakat yang dilayani. Menurut M. Solihin, dalam evaluasi koleksi kaitannya dengan pengembangan koleksi adalah sebagai berikut :

1. Penanggungjawab/wewenang atas pengelolaan perpustakaan

2. Metode pemilihan, anggaran, dan prioritas koleksi (pedoman/criteria koleksi dan timbangan buku/review)

3. Jenis-jenis bahan koleksi

4. Komposisi koleksi (kelengkapan, bahasa, periode/kronologis, cakupan geografis, format dibeli atau tidak, penanggungjawab koleksi)

5. Bahan berbahasa asing

6. Bahan perpustakaan berdasarkan format

7. Hadiah dan cara penangannanya

8. Pinjam, kerjasama dan jaringan antar perpustakaan

9. Criteria dan tata cara penyiangan

10. Sikap perpustaaan terhadap sensor dan masalah lain yang berkaitan dengan kebebasan intelektual (intellectual freedom)

\section{Evaluasi Koleksi Perpustakaan}

Evaluasi koleksi pada dasarnya menurut teori Evans G. Edward dan Elizabeth Futas adalah sama yaitu bagaimana pentingnya evaluasi koleksi bagi kebutuhan pengembangan koleksi sebagai bagian dari kegiatan yang harus diterapkan dalam perpustakaan. Dimana kegiatan evaluasi ini tentu memiliki proses, format dan metode. Menurut Elizabeth Futas, evaluasi 
koleksi adalah proses yg memberikan nilai untuk koleksi perpustakaan, berdasarkan kriteria:

1. Jenis bahan koleksi dan bagaimana menilai masing-masing dalam kaitan barang-barang lain di perpustakaan.

2. Jenis masyarakat di layani, dan layak tidaknya koleksi

3. Tujuan penilaian dari pengetahuan koleksi seharusnya untuk daftar kelompok/teman mengingat komunitas pembaca

Beberapa pertimbangan dalam evaluasi koleksi perpustakaan menurut Lasa (2009) :

1. Jumlah program studi

2. Jumlah mata kuliah (dasar umum, dasar keahlian, dan keahlian)

3. Tingkat pendidikan (universitas, institute, sekolah tinggi, maupun akademik)

4. Kegiatan penelitian

5. Banyaknya judul yang digunakan per mata kuliah

6. Jumlah dosen dan mahasiswa.

Evaluasi koleksi adalah untuk menilai koleksi secara kualitatif, untuk merencanakan pengumpulan bahan dalam jangka panjang dan untuk membantu dalam membuat keputusan dari sudut pandang manajemen di bidang anggaran, kepegawaian dan jasa karena melanggar atas koleksi, pengguna dan layanan yang disampaikan. Menurut Elizabeth Futas evaluasi koleksi dibedakan pada 2 permasalahan yaitu dari layanan publik dan layanan tekhnis perpustakaan dalam kegiatan evaluasi koleksi.

\section{a. Pengertian Evaluasi Koleksi}

Menurut Hartono (2015) evaluasi adalah mempertimbangkan nilai intrinsik bahan perpustakaan. Menurut Lasa HS, dalam kamus kepustakawanan Indonesia edisi revisi "evaluasi adalah kegiatan mengamati, mengoreksi, dan menimbang sungguh-sungguh tentang baik buruknya suatu masalah yang dilakukan oleh suatu tim secara formal dengan dasar, standar, pedoman tertentu dan pemberian penghargaan sesuai kualitasnya”. 
Masih menurut Lasa (2014) bahwasannya kegiatan evaluasi perpustakaan merupakan kegiatan penilaian yang dilakukan untuk meningkatkan kualitas dan kuantitas koleksi perpustakaan karena koleksi perpustakaan sangat berpengaruh pada eksistensi perpustakaan dalam pengembangan ilmu pengetahuan.

Menurut Maslahah (2015) kegiatan evaluasi akan lebih mudah dan tepat dengan adanya evaluasi keterpakaian koleksi dengan melalui pemustaka, analisis ini dapat juga digunakan untuk mengetahuai lebih jauh tentang paruh hidup dari suatu bidang ilmu. Menurut Evans (2005):

"The evaluation draws on information compiled from various sources personal examination of the shelves, qualitative measures, and the impressions of the service community. Subject specialists give their impressions of the strengths and weaknesses of a collection. Sometimes, the evaluator employs questionnaires and interviews to collect the data from many people. Less frequently, specialists' impressions may constitute the entire evaluation. Library staff member opinions about the collection add another perspective to the assessment; often, these views differ sharply from those of the users and those of an outsider."

Bahwa evaluasi dapat mengacu dari berbagai sumber, termasuk kekuatan dan kelemahan koleksi, anggota perpustakaan atau pemustaka dengan cara pendekatan, menyebarkan kuesioner, wawancara untuk mengunpulkan data, Dan atau pandangan dan penilaian pemustaka tentang koleksi. Sejalan dengan yang telah di ungkapkan bahwasanya kepuasan pemustaka terhadap kualitas jasa informasi perpustakaan merupakan program perpustakaan, yang berkaitan dengan produk dan jasa. Mutu atau kualitas koleksi mempunyai pengaruh terhadap kepuasan pemustaka (Elva Rahmah, 2019). Karena kepuasan pemustaka merupakan salah satu factor penting dalam pengembangan koleksi yang informatif, inovatif dan up to date.

Evaluasi (Elva Rahmah, 2015) dilakukan dengan teratur dan seuai jadwal yang berkala agar bahan pustaka yang tersedia datat diketahui sesuai atau tidaknya dengan perubahan dan perkembangan terhadap kebutuhan pemustaka. Setelah memahami manfaatnya maka dapatlah kita menngertahui tujuan dari evaluasi tersebut yaitu: 

a. Mutu, ruang lingkup, dan kedalaman koleksi
b. Menyesuaikan koleksi dengan tujuan dan program dari lembaga terebut
c. Dapt mengikuti perubahan, perkembnagan, sosial budaya, ilmu dan teknologi
d. Meningkatkan nilai informasi
e. Mengetahui kelemahan dan kelebihan koleksi
f. Menyesuaikan kebijakan penyiangan

\section{b. Tujuan dari evaluasi koleksi}

Menurut Khoirul M. dari (Yulia, 1993) tujuan dari evaluasi koleksi adalah:

1. Untuk mengetahui mutu lingkup dan kedalaman koleksi

2. Untuk Menyesuaikan koleksi dengan tujuan dan program lembaga yang diabwahinya

3. Mengikuti perubahan, perkembangan, sosial dan budaya, ilmu dan teknologi

4. Dapat meningkatkan nilai informasi

5. Mengetahuai kekuatan dan kelemahan koleksi

6. Menyesuaikan kebijakan penyiangan koleksi

\section{c. Metode Evaluasi Koleksi}

Metode evaluasi koleksi dapat dilakukan dengan cara kualitatif atau kuantitatif. Pertama dengan pendekatan kualitataif yaitu dengan melalui pendapat para ahli, daftar pemerikasaan koleksi (checking list) dan ikhtisar. Kedua melalui pendekatan kuantitatif dengan berdasarkan ukuran koleksi, menganalisis pengguna, dan membandingkan bibliografi perpustakaan lain. Kegiatan evaluasi koleksi ini diharapkan dapat memberikan masukan dan mengetahui seberapa efektif pemanfaatan pengembangan koleksi terhadap pemustaka dan untuk mengetahui keadaan koleksi perpustakaan tersebut. Unsur-unsur yang harus diperhatikan dalam mengevaluasi koleksi (Elva Rahmah, 2018), adalah:

a. Penulis/pengarang atau orang yang bertanggung jawab terhadap buku tersebut 
b. Judul buku

c. Volume sejumlah buku

d. Edisi, terbaru atau lama

e. Nama Penerbit, berdasarkan kualitas dari produksi yang dihasilkan

f. Waktu terbit, berisi informasi penting yang up to date atau terlama

g. Prakata, Tujuan penulisan buku tersebut

h. Pendahuluan, merupakan panduan untuk memahami buku tersebut

i. Daftar isi, Cakupan isi yang di sajikan

j. Naskah, batang tubuh buku

k. Lampiran

1. Glosari

m. Indeks

Metode evaluasi Evans sesuai dengan apa yang menjadi panduan dari ALA (America Library Assosiation) dalam melakukan tehnik evaluasi koleksi perpustakaan. dalam setiap langkah-langkah dalam metode evaluasi koleksi informasi perpustakaan.

Koleksi terpusat :

1. Memeriksa daftar, bibliografi dan catalog

Metode ini dilakukan untuk tujuan memeriksa daftar buku-buku, data secara objektif. Mengecek data kepemilikan bibliografi bahan pustaka, mengetahui standar bahan pustaka secara subyek dari amsing-masing lembaga perpustakaan dan pengguna.

2. Pendapat ahli

Metode ini di sebut juka tehnik impresionistik yaitu metode evaluasi dengan memeriksa koleksi sehubungan dengan tujuan dan kebijakan perpustakaan dalam hal laporan seberapa baik koleksi tersebut dalam memenuhi tujuan. Merupakan keahlian dari personal penilaian terhadap evaluasi koleksi, dengan cara: melihat daftar rak koleksi, wilayah subyek tunggal, rak bidang studi. Juga berdasarkan kedalaman koleksi dan kegunaan dalam akademik dan penelitian berdasarkan pada kelebihan 
dan kekurangan koleksi tersebut. Kegiatan evaluasi oleh para ahli tersebut dilakukan juga dala kegiatan yang melibatkan para pembaca dan komunitas layanan, dengan melihat dari kelebihan dan kelemahan koleksi, namun tak jarang pula melakukan penyebaran kuesioner dan wawancara untuk mengumpulkan data dari banyak orang. Terkadang juga meminta pendapat dari anggota staff perpustakaan tentang penialian koleksi.

3. Penggunaan statistik komparatif

Metode ini dengan melihat jumlah volume sebagai ukuran lebih kecil dari pertumbuhan koleksi perpustakaan dalam kaitannya dengan program dan layanan yang tersedia. Beberapa alat statistik yang di gunakan untuk kegiatan evaluasi koleksi yaitu alat evaluasi komparatif yang sering di gunakan secara luas yaitu produk yang di produksi oleh AMIGOS dan WLN. Kedua produk tersebut AMIGOS merupakan produk employed data yang berasal dari OCLN, sedangkan WLN menggunakan produk bibliografi sendiri. Dari penggabungn keduanya, produk WLN saat ini telah dikembangkan telah dapat memungkinkan kita untuk dapat membandingkan satu koleksi terhadap koleksi yang lainnya dalam berbagai klasifikasi perpustakaan. Saat ini produk/alat evaluasi koleksi automatic yang masih aktif adalah "Automatic Collection Analisis service" atau BPS dan terdapat 4 analisis yang tersedia:

1. Bachmarking dan alat perencanaann yang berguan untuk manganalisis koleksi berdasarkan subyek, usia, bahasa, format.

2. Aanalisis perbandingan

3. Analisis kesenjangan

4. Analisis perbandingan kepemilikan

4. Standar koleksi

Metode standar yang mencakup semua aspek perpustakaan, salah satunya bagian koleksi tercetak yang berhubungan dengan format. Standar yang bervariasi dari waktu kewaktu yang bergeser pada kuantitatif yang kemudian bergeser menjadi kualitataif dalam perbandingan jangka panjang bermasalah. 
Menggunakan terpusat :

1. Studi sirkulasi

Metode sirkulasi berupa layanan yang berhubungan dengan kurikulum dan pembelajaran universitas dan ini merupakan metode yang berhubungan dengan data sirkulasi koleksi perpustkaan sebagai bentuk kontribusi dalam proses pendidikan, seperti penelitin.

2. Pendapat user/studi

Metode ini dilakukan dengan cara mensurvei meminta pendapat kepada pemustaka dengan secra kuantity ataupun kuantitas. Melihat dengan secara baik dan buruknya koleksi terhadap kebutuhan mereka.

3. Analisis statistik salah

Metode yang menggunakan produk dari perpustakaan lain, yang saling berbagi tentang data pengguna koleksi.

4. Studi kutipan

Yaitu di tujukan untuk seleksi jurnal, metode ini juga dilakukan untuk akses koleksi pendidiakn dan manajemen sistem informasi (STM) perpustakaan dengan sampel penelitian dalam perpustakaan.

5. Dirumah digunakan studi

Metode variasi penelitian dalam mengatur berbagai lembaga yang menggunakan media pengguna dalam mencari materi. Fokusnya yaitu pada ketersediaan material dan yang tidak tersedia. Terdiridari dua metode studi:

1. Metode pencarian item spesifik

2. Metode pencaraian materi tentang topik/subyek

6. Ketersediaan rak koleksi

7. Studi penggunaan simulasi

8. Tes pengiriman dokumen.

Yaitu metode ulasan evaluasi terhadap dokumen, dalam penggunaan database.

Sedangkan metode yang dikemukaan oleh Elizabeth Futas dalam evaluasi koleksi yaitu ada dua jenis proses evaluasi koleksi/literatur yaitu: 
kualitataif konservatif dan kuantitatif bagi kebijakan pengembangan koleksi. Proses dari evaluasi koleksi dan konsep evaluasi koleksi itu sendiri menurut Futas dengan menilai standar kualitatif dengan melalui konsultasi dari orang yang berpengetahuan dan melalui perbandingan koleksi dengan standar general dan khusus bibliografi. Aspek dari evaluasi koleksi menurut Futas:

\section{Pertama.}

Metode evaluasi kualitatif yang paling penting dalam kegiatan evaluasi koleksi. Dengan metode S.E. Ifidon concluded:

1. Statistik teknik-regresi dan analisis beberapa multivariat

2. Caradaricon-trans, standar yang diterbitkan untuk koleksi

3. Analisis jumlah kutipan

\section{Kedua}

Metodologi kualitatif yang digunakan dalam evaluasi koleksi yaitu metode impresionistik atau observasi langsung. Kegiatan yang dilakukan oleh pustakawan yang telah memenuhi syarat dalam mengetahui koleksi dan menilainya berdasarkan latar belakang dan pengalamannya.

\section{Ketiga}

Metode survey terhadap pengguna dalam mengumpulkan informasi atau data, hal ini dilakukan untuk mengetahuai hal-hal sebegai berikut:

1. Mengevaluasi secara kuantitatif dan kualitatif efektivitas dari koleksi dan jasa dalam memenuhi kebutuhan pengguna.

2. Menyediakan informasi untuk membantu memecahkan masalah, memodifikasi program tertentu, atau menilai kebutuhan untuk layanan pengguna.

3. Menentukan susunan komunitas pengguna perpustakaan yang sebenarnya.

4. Mengidentifikasi kelompok pengguna yang membutuhkan untuk lebih dilayani.

5. Memberikan umpan balik tentang keberhasilan serta kekurangan. 
6. Meningkatkan hubungan masyarakat dan membantu pendidikan komunitas pengguna.

7. Mengidentifikasi perubahan tren dan kepentingan.

\section{Keempat}

Metode penerapan standar yang ditentukan pada koleksi perpustakaan. Standar ini bergantung pada jenis perpustakaan itu sendiri, dan juga tergantungdari varietasnya yang terbagi dua yaitu kuantitatif dan kualitatif. Hal ini memiliki criteria sebagai berikut :
a. Kriteria koleksi
b. Layanan
c. Staff

\section{Hasil atau manfaat evaluasi koleksi}

Pada artikel Jacqueline Borin and Hua Yi (2008), pelaksanaan evaluasi koleksi secara idealnya tentu memiliki tujuan untuk dapat memahami ketersedaian dan manfaat dari koleksi, maka kemudian kegiatan evaluasi koleksi itu dilaksanakan. Pada setiap perpustakaan tentu masing-masing memiliki rumusan dan indikator yang berbeda dalam perhitungannya, dan bagaimana pelaksanaan, metode, proses kegiatan evaluasi koleksi ini dilaksanakan. Beberapa indikator dalam pelaksanan evaluasi sebagai berikut:

a. Menurut kapasitas umum: adalah mengacu pada ukuran, umur dan pertumbuhan koleksi.

b. Standar subyek secara khusus: yaitu standar asosiasi professional yang telah ditetapkan.

c. Penerbitan ilmiah: berhubungan dengan kepemilikan dan tanggungjawab terhadap koleksi.

d. Pemakai: hal ini terbagi dalam tiga tingakatan, 1) bagaimana pemakai mengakses informasi. 2) kepentingan pemakai dalam mengakses koleksi. 3) bagaimana menggunakan informasi tersebut.

e. Pengguna: berhubungan dengan metode evaluasi yang berhubungan dengan pengguna dalam pengumpulan informasi atau data. 
f. Faktor lingkungan/konstruksi sosial: berkaitan dengan lingkungan atau lembaga tempat perpustakaan bernaung.

Pada informasi lain kegiatan evaluasi koleksi merupakan sebuah kegunaan dalam menilai dan memahami sebuah koleksi, mengapa evaluasi itu dibutuhkan. Bagi pustakawan dapat memberikan pemahaman. Secara fisik koleksi merupakan sebuah kesempatan untuk mengembangkan kesadaran koleksi secara keseluruhan. Memahami hubungan keberadaan dan kondisi untuk melakukan perbandingan, mengamati kelayakan koleksi yang tersedia dan untuk dapat memutuskan apakah pengadaan/pembelian buku di perlukan yang hal itu berhubungan dengan koleksi masa depan (Jim Agee, 2005).

\section{Kesimpulan}

Evaluasi koleksi merupakan kegaiatan mengoreksi, menilai bahan pustaka dengan melewati berbagai tahapan dalam kegiatnnya, bentuk kemajuan dan perkembangan dari pengadaan dan koreksi koleksi perpustakaan. Evaluasi koleksi pada sebuah perpustakaan merupakan kegiatan yang wajib dan harus dilaksanakan bagi layanan dan kepuasan pemustaka terhadap koleksi/informasi perpustakaan, dengan adanya evaluasi perpustakaan dapat diketahui dan mengukur kebutuhan dan kelayakan atau manfaat dari sebuah koleksi. Evaluasi koleksi menurut Evans dan Futes berdasarkan yang telah penulis uaraikan diatas maka dapat di tarik beberapa kesimpulan:

1. Evaluasi koleksi merupakan bagian dari upaya pengembangan koleksi perpustakaan

2. Memiliki tujuan dan manfaat dari segi nilai, juga dapat mengetahui kelebihan dan kekurang dari sebuah koleksi

3. Kegiatan evaluasi koleksi memiliki criteria dalam menilai suatu koleksi

4. Menggunakan metode baik Evans maupun Futas yang masing-masing tidak jauh berbeda

5. Merupakan sarana mengembangkan kesadaran terhadap kebutuhan koleksi dalam sebuah perpustakaan 


\section{Daftar Pustaka}

Arianto, Solihin. M. Dasar-Dasar Ilmu Perpustakaan dan Informasi, Yogyakarta: IAIN Sunan Kalijaga, 2003

Basuki, Sulistyo. Pengantar Ilmu Perpustakaan. Jakarta: Universitas Terbuka, 2010

Edward, Evans G., Margaret Z. Saponaro. Developing Library And Information Center Collection, United State: Libraries Unlimited, 2005

Futes, Elizabeth. Sheila S. Intner. Collection Evaluation, Univrsity of Illinois: USA, 2007

Hartono. Dasar-dasar manajemen perpustakaan dari masa-kemasa, Malang: UIN Maliki Press, 2015

. Manajemen Perpustakaan Sekolah Menuju Perpustakaan Profesional dan Modern, Yogyakarta: Ar-Ruzz Media, 2016

Lasa Hs. Kamus Perpustakaan Indonesia, Yogyakarta: Pustaka Book, 2009

Lasa HS. Kamus Kepustakawanan Indonesia, Yogyakarta: Pinus, 2014

Maslahah, Khoirul. "Evaluasi Pemanfaatan Koleksi Perpustakaan Dengan Menggunakan Analisis Sitasi Terhadap Sekripsi Mahasiswa Program Studi Pendidikan Agama Islam Tahun 2011 Di Pusat Perpustakaan IAIN Surakarta”, LIBRARIA Vol. 3 No.1, Januari-Juni 2015

Qalyubi.dkk, Syihabuddin. Dasar-Dasar Ilmu Perpustakaan Dan Informasi, Yogyakarta: Jurusan Ilmu Perpustakaan Dan Informasi UIN Sunan Kalijaga, 2007

Rahmah, Elva. Akses Dan Layanan Perpustakaan=Teori dan Aplikasi, Jakarta: Prenada Media Group, 2018 . Testiani makmur, Kebujakan Sumber Informasi Perpustakaan, Yogyakarta: Graha Ilmu, 2015 . Marliani, Gustina Erlianti. Manajemen Perpustakaan Penerapan TQm dan CRM, Depok: Rajawali Press, 2019

Soedibyo, Noerhayati. Pengelolaan Perpustakaan Jilid II, Bandung: Alimni, 1998 
Suwarno, Wiji. Perpustakaan dan Buku: Wacana Penulisan dan Penerbitan, Jogjakarta: Ar-Ruzz Media, 2011

Syukrinur. "Evaluasi Koleksi: Antara Ketersediaan dan Keterpakaian Koleksi”, LIBRIA, Vol. 9, No. 1, Juni 2017

Jacqueline Borin and Hua Yi. "Indicators for collection evaluation:a new dimensional frame work", Jurnal J-Stor, www.emeraldinsight.com Volume $27 \cdot$ Number $4 \cdot 2008$

Jim Agee, "Collection evaluation: a foundation for collection development", Jurnal J-Stor, www.emeraldinsight.com Volume 24 • Number 3 2005 Yueh-Min Huang and Ying-Hong Pu, "Development and evaluation of the mobile library service system success model A case study of Taiwan" Jurnal J-Stor, The Electronic Library www.emeraldinsight.com Vol. 33 No. 6, 2015 